\title{
Generation and characterization of individual- specific induced pluripotent cells from patient-derived lymphoblastoid cell lines
}

\author{
Shadaan Zulfiqar ${ }^{1 *}$, Radhika Menon ${ }^{1}$, Tara Atmaram, Meera Purushottam², Matthew Varghese², Sanjeev Jain², \\ Mitradas Panicker ${ }^{1}$, Odity Mukherjee ${ }^{1}$
}

From Molecular Neurodegeneration: Basic biology and disease pathways

Cannes, France. 10-12 September 2013

\section{Background}

Alzheimer's disease (AD) is a common neurodegenerative disorder that leads to cognitive impairment. In India, the prevalence of $\mathrm{AD}$ is currently $\sim 3.5$ million but due to its large population and the recent increase in longevity, is projected to increase to 7-9 million by 2020 . Thus, AD is a significant burden of disease in our country. Genetic variations play a major role in $\mathrm{AD}$. The apolipoprotein-E gene and in particular its $\varepsilon 4$ allele account for $20-50 \%$ of the total genetic variance in disease risk. One copy of $\varepsilon 4$ allele increases risk for AD by threefold, and two copies, by more than ten-fold. But still, $\varepsilon 4$ allele is neither necessary nor sufficient for the development of the disease, indicating involvement of other genetic risk factors, alone or in conjunction with the $\varepsilon 4$ allele underlying disease predisposition.

\section{Materials and methods}

Patient derived Lymphoblastoid cells (LCLs) carrying predisposing APOE4 allele was used to generate induced pluripotent stem cells (iPSCs) using episomal plasmids. Post characterization, theiPSC lines were differentiated into neuronal lineage using retinoic acid induction method. Whole genome transcriptome analysis was performed using RNA isolated from MAP2/Tuj1 positive cells (17-22 DIV). Protein expression studies (by Western Blot) for key molecules was also performed to validate the above results.

\section{Results}

We have successfully generated iPSC lines from AD patients and cognitively normal controls $(n=6)$. These

${ }^{1}$ NCBS-TIFR, Bangalore, Karnataka-560065, India

Full list of author information is available at the end of the article lines display human embryonic stem-cell like morphology and transcription profile. These cells gave rise to neurons on directed differentiation that were positive for neuronal markers MAP2 and Tuj1. Whole genome transcriptome analysis of differentiating neurons derived from patient iPSCs with varying APOE genotype showed significant differential expression of coding and pseudogenes in implicated pathways. Briefly, genes encoding for focal adhesion molecules, glutamatergic synapses, axon guidance and cell adhesion protein showed differential expression patterns. Preliminary protein expression studies performed on parent LCL lines have confirmed some of transcriptome signals suggesting usefulness of peripheral models to interrogate complex phenotypes like AD.

\section{Conclusion}

Most patient-specific iPSC lines reported use viral transduction as the mode of gene delivery for reprogramming. This may affect the phenotype and mechanism of the disease in question. We have generated iPSC lines using an integration-free method using LCLs. the derived LCL lines are stable for a large number of passages and serve as an alternate cell model to test experimental leads. As a preliminary step to test the validity of patient derived iPSCs to model AD, we have used whole genome RNA sequencing analysis. We show APOE allele- specific difference in expression profile of genes in key disease pathways. We are currently validating these leads in a larger patient sample.

\section{Authors' details}

${ }^{1}$ NCBS-TIFR, Bangalore, Karnataka-560065, India. ${ }^{2}$ Department of Psychiatry, NIMHANS, Bangalore, Karnataka-560029, India. 


\section{doi:10.1186/1750-1326-8-S1-P53}

Cite this article as: Zulfiqar et al:: Generation and characterization of individual-specific induced pluripotent cells from patient-derived

lymphoblastoid cell lines. Molecular Neurodegeneration 2013 8(Suppl 1):P53.

Submit your next manuscript to BioMed Central and take full advantage of:

- Convenient online submission

- Thorough peer review

- No space constraints or color figure charges

- Immediate publication on acceptance

- Inclusion in PubMed, CAS, Scopus and Google Scholar

- Research which is freely available for redistribution

Submit your manuscript at www.biomedcentral.com/submit 